\title{
Organizational Performance and Chief Executive Officer's (CEO's) Compensation for Firms Listed in Nairobi Securities Exchange, Kenya
}

\author{
Omamo Anne, \\ Prof. Peter K'obonyo, \\ Dr. Florence Muindi,
}

Jomo Kenyatta University of Agriculture and Technology, Kenya

Doi:10.19044/esj.2020.v16n19p498 URL:http://dx.doi.org/10.19044/esj.2020.v16n19p498

\begin{abstract}
This study examined the link between organizational performance and CEO'S compensation of firms listed at the NSE. Past studies on the determinants of CEO'S compensation revealed a lack of consensus to the explanation of increases in CEO'S compensation. While most of the studies confirm linkages between organizational performance and CEO'S compensation, they measured organizational performance using financial indicators of performance, the current study investigates the relationship between organizational performance and CEO'S compensation but differs from the previous studies by expanding the measures of organizational performance to include the balanced scorecard measures of performance. The theoretical foundations of this study were based on agency theory. The study's population constituted 60 firms listed at the NSE. Descriptive crossectional survey was adopted for this study. Both Primary and Secondary data were used to gather information required for the study. Descriptive statistics and regression were used to analyze and interpret the collected data. The study revealed that there was significant and positive relationship between organizational performance and CEO'S compensation. The findings of this study are of benefit to board members of organizations in identifying the performance measures that are important to consider when making decisions on CEO'S compensation.
\end{abstract}

Keywords: NSE, CEO's, Security Exchange

\section{Introduction}

As today's business environment become increasingly complex and global, they are faced with the challenges of managing continuous change, competition, cost constraints, increasing employee demands, legal 
requirements among others. Human Resource Management is seen as a major contributor in helping the organizations deal with these challenges by designing ways to effectively increase employee's productivity and commitment. To this end, one area of concern to human resource managers is the implementation of employee compensation programs that would satisfy employees' needs as well as contain the costs of labor for the firms (Bernardin, J. 2007). In trying to achieve this, firms have continuously seen the need to tie employees' levels of pay especially the executives to the levels of individual and organizational performance. As such decisions on designing the CEO'S compensation are crucial to an organization since they are responsible for the overall performance of the organization. One of the concerns in compensation management today is the variation in Chief Executive Officer's compensation. Literature indicates that CEO'S compensation levels vary from firm to firm and from industry to industry but there is no explanation for these variations. This study seeks to find out explanations to these variations by re-examining the influence of organizational performance, CEO'S power and firm size in the determination of CEO'S compensation levels.

According to Sonenshine et al, (2016) the debate on CEO'S compensation is largely centered on two view points. That is, whether the CEO'S earn their compensation through organizational performance and productivity or whether the CEO'S simply capture their compensation through extraction of rent due to weak board or poor governance. The first view proposing that CEO'S compensation ought to be associated to observable organizational performance measures like stock prices and earning so as to motivate the CEO'S to enhance organizational performance. On the other hand, the second view argues that CEO'S compensation is affected by the availability of rents and the bargaining power that the CEO'S have over the board of directors and shareholders. Equally, empirical studies have been able to establish that organizational size also influences CEO'S compensation and that larger organizations generally offer higher compensation to their CEO'S.

Organizational performance can be characterized as the firm's ability to create acceptable outcomes and actions (Reed et al, 2000). It comprises the actual output or results of an organization as measured against its intended outputs, goals or objectives. Upadhaya B. et al, (2014) propose that in recent years, many organizations have attempted to manage organizational performance using the balanced scorecard methodology where performance is tracked and measured in multiple dimensions such as financial performance, customer service, social responsibility and employee stewardship. Organizational performance from the stakeholder's perspective can be viewed as having met the expectations of a variety of stakeholder groups like employees, customers, suppliers, governments, local communities that have 
particular interest in the effects of the organization's activities. Organizational performance has been strongly associated to CEO'S performance (Epstein \& Roy 2005, Jensen and Murphy 1990, Wade Porac \& Pollock 1997 and Baptista, 2010). Another factor that could explain the variations in CEO'S compensation is the power of the CEO to influence their own pay. CEO'S are considered to be the most powerful corporate actors although some are more powerful than others. The power of the CEO to influence the board's decisions and shape the strategy of the organization is one of the salient issues in corporate governance (Malekzadeh, 2002). This influence over the board by the CEO may extend the decisions on their pay structure. Firms vary in characteristics in terms of size, age, reputation, nature of business and ownership structures. These variations may explain the differences in their performance level and as such the CEO'S compensation. This study considered firm size, ownership structure thus whether public or private firm and industry type/ sector in describing firm size.

This study focused on the firms listed at the NSE as its context. The NSE consists of firms that can be categorized as public owned of private owned firms. The NSE consists of 65 firms in various industry sectors that can be categorized into 8 sectors namely agriculture, automobiles and accessories, banking, commercial and services, construction and allied insurance, investment and manufacturing and allied. This provides an environment that allows for comparisons of CEO'S compensation among the various firms with reference to their performance, characteristics and CEO'S power. It was expected that listed companies comply with the NSE and CMA regulations for them to continue selling at the browse. The Nairobi Securities Exchange has in place very strict and elaborate listing regime at the bourse, including disclosures, reporting obligations, financial requirements, records to be maintained, code of conduct, self regulations, submission of annual budget, and other corporate governance requirements. The listing requirements, though strict and at times viewed as inhibitive, are necessary to ensure that only the best managed companies find their way to the Nairobi Security Exchange. These requirements for the firms to be listed at the NSE provides a good ground to conduct the study and CEO's compensation due to easy access to relevant data on organizational performance.

The next section provides definitions of the key study variables.

\section{Organizational Performance}

The definition of organizational performance as proposed by several writers is based upon the idea that an organization is a voluntary association of productive assets, including human, physical and capital resources, for the purposes of achieving a shared purposes or goal (Alchian \& Demsetz, 1972. Barney, 2002; Jensen \& Meckling, 1976; Simon, 1976). There are two main 
ways in which we can think of the theory of the firm and each has different implications for reporting organizational performance. These are the shareholder theory and stakeholder theory (Owen, 2006, Brown and Fraser, 2006). In the 1980's the firm was viewed as belonging to shareholders and so the shareholder theory, which uses shareholder return to measure overall firm performance dominated organizational performance measurement system, (Porter, 1980). However since the early 1990's a more stakeholder based view gradually began to prevail. This perspective views the firm as having responsibilities to a wider set of groups than simply shareholders. Other stakeholders include employees, customers, suppliers, governments, industry bodies, local communities and so forth (Reich, 1998, Post et.al, 2002, Brown and Fraser, 2006). It assesses organizational performance against the expectations of a variety of stakeholder groups that have particular interests in the effects of the organization's activities.

Wade et. al. (1997) propose that the performance of public held companies can be broken down in three components namely; accounting returns and profitability, stock market returns and 'beta' which measures the volatility of a company's stock price relative to broad market indicators. They further argue that high accounting returns like return on equity, imply that management has been successful in balancing revenues and costs and making good use of organizational assets to create value. Market returns represent the collective opinion of investors on the organizational abilities to generate wealth. Such that higher shareholder returns legitimize management. Epstein and Roy (2005) argue that in the past years, researchers have suggested a number of management systems to hasten the development of critical measures that can guide long term corporate decision (Eccles, 1991; Ittner and Larcker, 1998; Kaplan and Norton, 2000). These managerial systems mainly rely on the identification of organizational strategic objectives, the key performance, indicators and drivers and a wider set of both financial and nonfinancial measures of performance. Growing importance has been given by academicians and consultants to the balanced scorecard approach as a useful tool for the development.

One dominant approach which has been universally accepted to measure organizational performance is the Balance Scorecard (BSC) system by Kaplan and Norton (1992) which is based on the stakeholder theory. The BSC incorporates financial, customer/market, short-term efficiency and longterm learning and development factors. Mooraj et.al, (1999) argues that although the BSC's are common, they are primarily a tool for measuring external and internal economic value. This study therefore adopts the BSC approach of organizational performance measurement. 


\section{CEO'S Compensation}

Bernardin (2007) defines compensation as all forms of financial returns and tangible benefits that employees receive as part of an employment relationship. Executive pay is financial compensation received by senior managers of a firm. It is typically a mixture of salary, bonuses, shares and or call options on the company stock, benefits and perquisites, ideally configured to take into account government regulations, tax law, the desires of an organization and the executive, and performance (Elling 2002). The mixing of the different components of pay into a complex compensation package for executives allows the shortcoming of one component to be offset by the strength of another. Cash bonuses focus executives on the immediate success of the firm by paying them for reaching short-term goals. This counters the shortcoming of restricted stock that base awards on the long run outcomes and does not pay rewards for short-term production. To reduce the problem of the company stock price moving based on market forces and not that of the executive's movement of a market index of stocks (Sigler, 2011). Over the past three decades, executive pay has risen dramatically relative to that of an average worker's wage in the United States, The Guardian, 2005, and to a lesser extent in some other countries. Observers differ as to whether this rise is a natural and beneficial result of competition for scarce business talent that can add greatly to stakeholder value in large companies or a social harmful phenomenon brought about by social and political changes that have given executives greater control over their own pay, (Bebchuk and Fried 2004). Executive pay is an important part of corporate governance and is often determined by a company's board of directors.

A major challenge that scholars encounter in trying to understand the factors that determine CEO'S compensation is the various components that constitute the total remuneration of CEO'S compensation package. Besides the terms used by researchers, industry and countries are not consistent and tend to cause confusion. A case to mention is that performance share plan is a commonly used term in the United Kingdom as opposed to long term incentive plan (LTIP) in the US which refers to the same type of plan. Adopting Farmer (2008) definitions; a basic pay could be provided to CEO'S on a monthly basis and is a constant amount with no risk of non-payment. The CEO'S are also offered a bonus which is at risk of non-payment since it is dependent of organizational performance. This highest bonus is paid when performance goes beyond the upper threshold yet no bonus will be paid for performance below a lower threshold.

CEO'S are eligible to receive grants of share options within the rules of long term incentive plans. The value of the share option will move in the same direction with the company share price hence they are also at a risk of decreasing in value just like the bonus. Most CEO'S are also entitled to 
benefits such as club membership, driver, housing allowance, security, education, holidays, medical covers among others. Most organizations also provide the CEO'S with a retirement plan. Going by disclosures ont eh annual reports of firms listed at the NSE, CEO'S compensation largely consists of salaries, allowances, cash bonuses and fees for services as directors (Aduda, 2011). Sigler (2011) writing on the components of CEO'S compensation for American firms, noted that the first component of CEO'S compensation is base salary which comprises $11.2 \%$ of their compensation. Going by the study by Economic Research Institute in 2010, CEO'S base salaries are determined by the opinion of compensation committee who largely consist of the members of the board of directors.

Secondly, CEO'S compensation include incentive plans consisting of cash bonuses which are paid in lumpsum at the end of the financial year as a way of motivating performance of the CEO. Bonuses act as incentives which are paid to the CEO'S upon attaining previously set goals. Bonuses are linked to accounting measures and are highly associated to the CEO'S specific areas of responsibility. They are aimed at motivating the CEO to pay more attention on the company's key objectives of increasing shareholder value and in turn their own wealth. Bonuses may be provided in association to the achievement of short-term, intermediate term, or even long term goals of an organization. A third component of CEO'S compensation could be seen as executive stock options which also act as an incentive to the CEO'S. The stock options could be provided in various forms including qualified incentive stock options and non qualified stock options which are used by many organizations as forms of equity compensation for CEO'S to drive them towards working in the best interest of shareholders. The qualified stock options provide a tax benefit but they equally have complicated tax consequences. Non qualified stock options have a draw back to the CEO'S since taxable income is usually reported at the time when the non-qualified options are exercised without the consideration of whether the stocks have been sold or not. Qualified stock options mitigate this disadvantage since they do not report any income at the time they are exercised unless the stock is sold. Executive stock options tend to reduce greater risk aversion by providing the CEO'S an incentive to increase organizational risk by allowing risky but profitable projects as opposed to avoiding them.

A fourth form of CEO'S compensation is the restricted stock ownership of an organization which merges the interest of shareholders and the CEO'S. Restricted stock limits the shares that a CEO can own. A common restriction is the imposition of the time period that has to elapse or for the achievement of particular goals before the CEO can cash in the stock. A fifth compensation component for CEO'S is a golden parachute that consists of lucrative benefits that CEO'S are offered in the event that the organization is 
taken over by another firm causing the CEO to lose their job. Specifically, the golden parachute items include: stock options, severance pay and bonuses. The sixth and last component of CEO'S compensation constitutes benefits that go to the CEO and includes retirement plans, life insurance, medical cover, car allowances, club membership, travel re-imbursements, paid holidays and vacations. The table below provides a summary of the key components of CEO'S compensation and their alternative names.

\section{Literature Review}

According to Ozkan (2011), the compensation package of CEO'S has been viewed as an important factor in resolving the conflict of interest between executives and shareholders of organizations. Organizations today have come to the recognition that CEO'S compensation could be a useful tool in motivating CEO'S to act in the best interest of the organizations. The rapid increase in CEO's compensations has provoked renewed interest in understanding the factors that determine CEO's compensation. At the centre of the debate are arguments concerning whether the compensation increases are earned by the CEO's due to good performance and productivity or whether it is the CEO who have power to drive their pay upwards by extracting rents from a weak board (Sonenshine et al, 2016).

\section{Organizational Performance and CEO'S Compensation}

Firm performance is argued to be the major determinant of CEO compensation and that on the basis of literature; firms should compensate their CEO'S depending on how much they bring to the firm. Previous studies by Buigut, et al, (2014); Chalmer \& colleagues, (2006); Kubo, (2001); Fenkelstein, Hambrick, (1989), indicate that firm performance is positively related to CEO'S compensation. Ozkan (2007) suggests that in the UK, organizational performance has a positive relationship with CEO's compensation and this applies more with the cash forms of compensation. While other studies like, Tarus, et al, (2014); Flrming \& Stellios, (2002); Izan et al, (1998); Jensent \& Murphy, (1990), show a weak or negative relationship between firm performance and CEO'S pay. A number of firm specific characteristics like size can be thought of as influencing executive compensations. Brick et al, (2005) found a strong but negative relationship between organizational performance and CEO's compensation. Shah and Javed, (2009) observed that organizational performance is considered to be perhaps the most significant determining factor of CEO'S compensation. Historically, literature on CEO'S compensation provides an emphasis that CEO'S compensation should be linked to organizational performance. Some academic studies suggest CEO'S compensation to be better predicted by profit. According to Fenkenlstein \& Hambrick, (1989) and Deckop (1988), 
organizational profitability is strongly related to CEO'S compensation while return on equity is unrelated to CEO'S salary but positively associated to bonuses that CEO'S receive. However, some studies record contradicting results on the relationship between organizational performance and CEO'S compensation. There is a weak relationship between CEO'S compensation and stockholders wealth (Jensen \& Murphy, 1990). Fleming \& Stellions, (2002) also found no relationship between organizational performance and CEO'S compensation. Chalmers \& Colleagues (2006) revealed that return on asset was strongly related to all components of CEO'S compensation and that CEO'S bonuses are related to annual stock market returns.

Farmer (2008) argues that literature on CEO'S compensation has considerably increased over the last 60 years and covers an array of disciplines including accounting, economics, law and organizational strategy. Accountants like Healy (1985) in his studies considered the link between accounting based compensation incentives and manipulation of earnings. Baimen and Verrechchia (1995) also accountant, explored the relative effectiveness of accounting-based compensation and market-based performance measures. Jensen and Murphy (1990) who were financial economists, focused their studies on the relationship between CEO'S compensation and organizational performance. They also studied the influence investment decision, capital structure, dividend policies mergers and diversification on CEO'S compensation. According to Wade et.al; (1997) the amount of compensation a CEO receives is on one-half of the current debate on pay-for-performance. The other half is about the actual performance or organizations. Poor organizational performance sparks scrutiny of investors who are seeking to place the blame of poor performance on management. On the other hand when organizations report high performance justification for higher CEO compensation is eased by relaxing legitimacy threats.

The principal-agent problem has partially resolved using CEO'S compensation so as to align the CEO'S interest with the interest of sharehlders (Jensen \& Meckling, 1976). Holmstrom (1982) argue that in principle, the compensation of CEO'S should be pegged on the most informative indicators in terms of whether the CEO has taken action that maximize shareholder's value. Since in reality the shareholders are not likely to understand or know the particular actions that maximize value, the incentive forms of compensation offered to CEO'S should be those that help the principals achieve their ultimate objective of shareholder value maximization. Through the effective designing and provision of ownership stake to a firm, compensation offered to CEO'S that are linked to equity, creates a motivating force for the CEO'S to take actions that benefit shareholders. Optimal contract helps balance the provision of incentives to CEO'S against exposing risk averse CEO'S to much volatility in their compensation. 
Previous literature generally shows a strong relationship between organizational performance and CEO'S compensation where firm performance is measured by return on asset (ROA) and return on equity (ROE) (Finkelstein Hambrick, 1989 and Kobo, 2001). They argue that the profitability of firms is a better determination of CEO'S compensation. According to Guest (2009) there is a positive relationship between board size and CEO's compensation. Board members are an important source on internal control mechanism in setting CEO's compensation. They also have the responsibility in deciding the succession of the CEO and future projects of the organization (Rahaja, 2005). Core et al, (1999) argue that CEO's compensation is influenced by a number of factors including firm performance, firm size, complexity of firm, growth opportunities and board structure. Concerning the pay-performance relation, there is wide evidence for a strong relation in the US. Jensen and Murphy (1990) found a positive and significant relation between cash compensation and firm performance measured by shareholder wealth. In addition, Joskow and Rose (1994) suggest a robust relation firm performance measured by both market-based and accounting measure and total compensation.

Jensen \& Meckling (1976) observed that it is important to align organizational performance with CEO'S compensation. They demonstrated that a CEO with less than sole ownership of the organization usually is motivated to take actions that may decrease organizational value. When designing CEO'S compensation structure, organizations will provide longterm executive stock options in an attempt to motivate the CEO to act as an owner would do. Leonard (1990) asserts that when CEO'S are offered long term incentive plans, there will be an increase in organizations return on equity as opposed to those firms that do not offer long-term incentive plans. Jensen and Murphy (2010) also proposed that the compensation of CEO'S in most public companies is highly associated with organizational performance.

Rose and Joskow, (1994) found that past performance influences not only cash compensation, but also total compensation. In line with Jensen and Murphy, they found that the lagged performance effect decays considerably over two to three years. They used not only market-based measures of performance, but also accounting measures. For stock return, they find that 1year lagged return has at the least the same impact on current compensation than current return, but that further lags have a small effect on compensation. For accounting returns, they find that the returns effect compensation decays almost proportionally over time. Other studies show no relationship between organization performance and CEO'S compensation (Fleming \& Stellio, 2002, Izan et al, 1998, Defina et.al., 1994). Tosi \& Collegues (2002) also found a week relationship between CEO'S compensation and firm performance. 
Chalmers \& Colleagues (2006) show that ROA is positively associated with all compensation components except shares.

Aduda, (2011) conducted a study on the relationship between executive compensation and firm performance on commercial banks listed at Nairobi Securities Exchange and the results indicated that accounting measures of performance are not key considerations in determining executive compensation among the banks in Kenya and that instead size is a key criterion in determining executive compensation. These two studies only focused on the directly compensation in specific industries. The current study expands performance measures to include operational and market based measures among all the firms listed in Nairobi Securities Exchange which has a representation of companies in various industries. Wade, Porac, and Pollock, (1997), conducted a study on how the compensation committees of a sample of U.S corporations from the $\mathrm{S}$ and $\mathrm{P} 500$ justify their compensation practices to shareholders. They found that when companies have more concentrated and active outside owners, they are much more likely to justify their compensation practices by citing the role of compensation consultants as advisors in the compensation-setting process. They are also more likely to discuss the alignment of managerial and shareholder interests and to downplay a company's accounting returns. Companies that pay their CEO'S large base salaries are also more likely to cite the role of consultants and for those with dispersed ownership, to discuss shareholder alignment. High accounting returns lead companies to emphasize accounting performance in their compensation justification and to downplay market returns. Another study by Epstein and Roy, (2005) on evaluating and monitoring CEO'S performance found that although there are a growing number of companies using nonfinancial metrics to evaluate CEO'S performance, their results confirmed that CEO'S are primarily evaluated on financial criteria, indicating a narrow definition of corporate performance. In the current study organizational performance is considered as a reflection of CEO'S performance and is measured in terms of SBSC measures.

Most of studies on executive compensation have been carried out in the context of American and European organization. Khana and Palepu, (1997), have pointed out that the significant differences in the institutional context in which firms in emerging markets like Kenya operate. In Kenya the effect of economic liberisation along with a wide range of changes in the market for managerial talent has resulted in significant changes in the compensation policies adopted by firms. The studies reviewed above show that there are relationships between organizational performance, CEO'S power, firm size and CEO'S compensation. A majority of the studies focused on the relation organizational performance as the key determinant of CEO'S compensation with most of them finding positive relationships and a few 
others revealing weak or even negative associations. Besides the studies measured firm performance largely by accounting indices.

The current study starts by arguing that indeed organizational performance determines CEO'S compensation but expands the performance measures in line with the sustainable balanced scorecard. Besides very few of the previous studies consider the combined effect of the determinant of the CEO'S compensation. The current study seeks to establish the effect of organizational performance on CEO'S compensation as its key objective.

\section{Theoretical underpinning}

To shed new light on the ongoing controversy on CEO compensation, the study was grounded on agency theory. According to Abed et al. (2004) it is through organizational practices and theoretical arguments that discussions on determinants of CEO remuneration are far from ending. However, although various theoretical positions proposed to elucidate remuneration, this are of study is still largely dominated by the "agency theory". Key concern of "agency theory" has to do with associations that are likened to the nature of relationships that exist between an agent and a principle who contracts them to work for them. However, it is expected that between the agent and the principal their needs will defer (Eisenhardt, 1989). The theory seeks to provide solutions to the conflicts that may emerge in an agency relationship. The initial conflict that may arise is a situation where the needs of the principal and the agent do not merge and another problem is the difficulty that the principal is likely to face in trying to follow up what the contracted individual is up to. Thus the principal is unable to check if the agent has acted in an acceptable manner.

Agency theory proposes that:

The owners of a firm delegate authority to make strategic decisions on their behalf to an agent: the CEO. Agency theory highlights the existence of an agency problem: a CEO and the firm's shareholders often have differing interest such that the CEO may make moves that are in her best interests even if they hurt the firm (Jensen \& Mackling 1976).

The shareholders' main watchdog is the board, whose job includes monitoring the CEO and managing the CEO'S compensation package. Ideally, the board will craft a compensation package that aligns the CEO'S goals with those of the shareholders (Elsenhardt, 1989). Many boards for example emphasize stock options and other forms of contingent compensation. By drawing a connection between the CEO'S pay and firm performance, the board strives to motivate the $\mathrm{CEO}$ to pursue courses of action that maximize shareholder returns. In crafting a compensation package, the 
board should consider not only the overall value but also the mix of the pay elements in the compensation package. Rather than determining how much to pay executives, the central legitimizing issue in the agency approach is how to pay them (Barkema, Geroski, and Schwalbach, 1997; Jensen and Murphy, 1990). Pay is seen as a consequence of agency problems, the question how to pay the executive is the main issue addressed in these theories. Agency problems exist in any situation where one party entrusts responsibility of tasks to another party".

The agency problem could partially be resolved using executive compensation by matching the needs of a manager to needs of owners (Jensen and Meckling, 1976). Organizations hope that by offering CEO'S the chance to partially own their firms through equity-linked compensation, the CEO'S would be steered to act for the benefit of owners.

\section{Conceptual Framework}

The conceptual model of this study considered how Organizational performance affect the determination of CEO'S compensation. It showed that organizational performance is the main factor that firms considers in making CEO'S compensation decision. Organizational performance is measured on the basis of balanced score card elements including financial measures, customer satisfaction, internal processes success, learning and growth strategies. This is tested with hypothesis studies hypothesis which states that; Organizational performance has influence on CEO'S compensation.

Figure 1: Conceptual Framework

\begin{tabular}{|c|c|}
\hline $\begin{array}{l}\text { Organizational performance } \\
\text { - Financial indicator } \\
\text { - Customer satisfaction } \\
\text { - Internal process } \\
\text { - Learning and development }\end{array}$ & $\begin{array}{c}\text { CEO'S Compensation } \\
\text { Total compensation }\end{array}$ \\
\hline
\end{tabular}

\section{Research Design}

\section{RESEARCH METHODOLOGY}

The study adopted the positivist approach as the basis for the methodology and procedures used in this study. This approach allowed use of quantitative data to test the research hypothesis drawn from the theoretical framework.

Descriptive cross-sectional design was adopted for the study. Crosssectional studies are carried out once and represent snapshot at one point in time (Cooper and Schindler, 2008). A descriptive cross-sectional design enabled the researcher to establish any relationships between and among organizational performance, and CEO'S compensation of firms listed in NSE. 
Financial data was collected for the period 2016/2017. The design was chosen considering the type of data and the analysis that is carried out.

The relevant population for the study comprised all companies listed at the Nairobi Securities Exchange (NSE). According to the Nairobi Securities Exchange Handbook 2016, the total number of listed companies at the browse was 60. This study was therefore a census survey of all listed companies. Data on financial performance was obtained from financial reports filed with capital markets authority (CMA).Data on firm size was also collected from the source.

\section{Data Collection and Analysis}

The study used primary and secondary data to test the hypotheses. The primary data on organizational performance and CEO'S compensation collected using a structured questionnaire. The questionnaire was researcheradministered to the firms' directors with assistance from the company secretaries who are also the secretaries to the board. The questionnaire gathered data on the Organizational performance and CEO'S compensation. The questionnaire was on Likert-type statements anchored on five-point rating scale ranging from none (1) to very high (5). This approach was also applied in related studies like Kidombo (2007), Ongore (2008) and Chang (2010). Secondary data on organizational performance (return on assets) was extracted from organizational financial reports.

Data was analyzed using descriptive statistics in order to describe the main characteristics of the variables of interest in the study. Pearson's Product Moment Correlation ( $\mathrm{r}$ ) analysis was used to assess the strength and direction of the relationships between study variables. Coefficient of determination $\left(\mathrm{R}^{2}\right)$ was used to measure the amount of variation in the CEO'S compensation due to the predictor variables.

\section{Research Findings And Discussion}

Questionnaires were administered to all the 60 firms. However, responses were only obtained from only 40 firms. This represents a 66.67 percent response rate which is considered representative and satisfactory to draw conclusions for the study. Although the intention was to randomly collect data from four directors in each firm, in reality, this was not possible. However, due to the sensitive nature of this study, and based on the promise of confidentiality, the names of the companies from which data was collected are not disclosed. 


\section{Research Findings \\ CEO'S compensation}

The study sought to investigate the percentage adjustment of the CEO'S pay between 2015 and 2016. Findings revealed a positive adjustment on the CEO'S pay with an average of 3.325 thus implying to $6-10 \%$ increment in CEO'S compensation.

\section{Organizational Performance (OP)}

Organizational performance was the study's independent variable. To determine the relationship between organizational performance and the other study variables, it was important to seek the Respondent's opinion on the extent to which they would consider it in determining the CEO'S performance and as such the level of compensation offered to the CEO. Organizational performance was measured using a 5 point Likert scale where the rating of 1 indicated very large extent to 5 representing not at all. Therefore a score of $\leq 1.5$ was interpreted to mean considered to a very large extent, while scores of 1.5 to $\leq 2.5$ indicated that the respondents considered the item to a large extent and 2.5 to $\leq 3.5$ was interpreted to mean that the respondents moderately considered the item. As for the mean scores a mean of 3.5 to $\leq 4.5$ was interpreted to mean that the respondent considered the variable to a less extent, while a mean score of $\geq 4.5$ was interpreted to mean the variable was not considered at all. In terms of the standard deviation, a value of $\leq 1$ was interpreted to mean that the Respondents agreed in the rating of the statement while a value of $>1$ was interpreted to mean Respondents differed in their opinion about the statement. 18 items were used to measure organizational performance in the listed firms. These items were adopted from the balanced score card as used by Kaplan and Norton (1996) that measures organizational performance in 4 dimensions of financial indicators, management of customer relations and growth, internal processes and learning and growth. The Respondent's opinion relating to the variable under each of the 4 dimensions of organizational performance is presented in the following sub-sections.

\section{Test of Hypothesis}

This study's hypothesis was stated as; CEO'S Compensation is influenced by Organizational Performance.

Simple linear regression analysis was used to test this hypothesis. In order to be able to apply parametric statistics such as multiple regression and correlation, it is paramount that the sample data be normally distributed and homogenies in nature. Since the study used linear regression to test the study hypothesis, preliminary tests were done to confirm normality and linearity to ensure it meets the requirements. Initial analysis on the data was done to assess if it fits normal distribution requirements. Data normality was 
determined using Skewness and Kurtosis values, where skewness is a measure of distributions deviation from symmetry while Kurtosis is a measure of a distribution's peakedness (Cooper and Schindler, 2014). Skewness value of zero shows perfect normal distribution. As shown in table 2, CEO'S compensation and organizational performance, did not extremely deviate from normal distribution assumptions and as such meeting the requirements to run regression analysis.

Table 2: Results of tests of normality

\begin{tabular}{lll}
\hline Variable & Skewness & Kurtosis \\
\hline CEO’S compensation & -1.484 & 1.445 \\
Organizational performance & 0.384 & -0.398
\end{tabular}

Linear regression analysis requires that data must be linear and as such there should be no multicollinearity or autocorrelation. A scatterplot was used to test for linearity and indicated that the variables were related in a linear fashion.

Table 3: Results of Inter-variable Correlation analysis

\begin{tabular}{llll}
\hline & CC & OP \\
\hline & Pearson Correlation & 1 & \\
CC & Sig. (2-tailed) & & \\
& N & 40 & \\
OP & Pearson Correlation & $.490^{* *}$ & 1 \\
& Sig. (2-tailed) & .001 & \\
& N & 40 & 40
\end{tabular}

The correlation matrix in Table 3 was derived from inter-item correlation analysis. The result for testing multicollinearity was less than 1 hence indicating that there was no multicollinearity.

Table 4: Regression Results for the Influence of Organizational Performance on CEO'S

Compensation

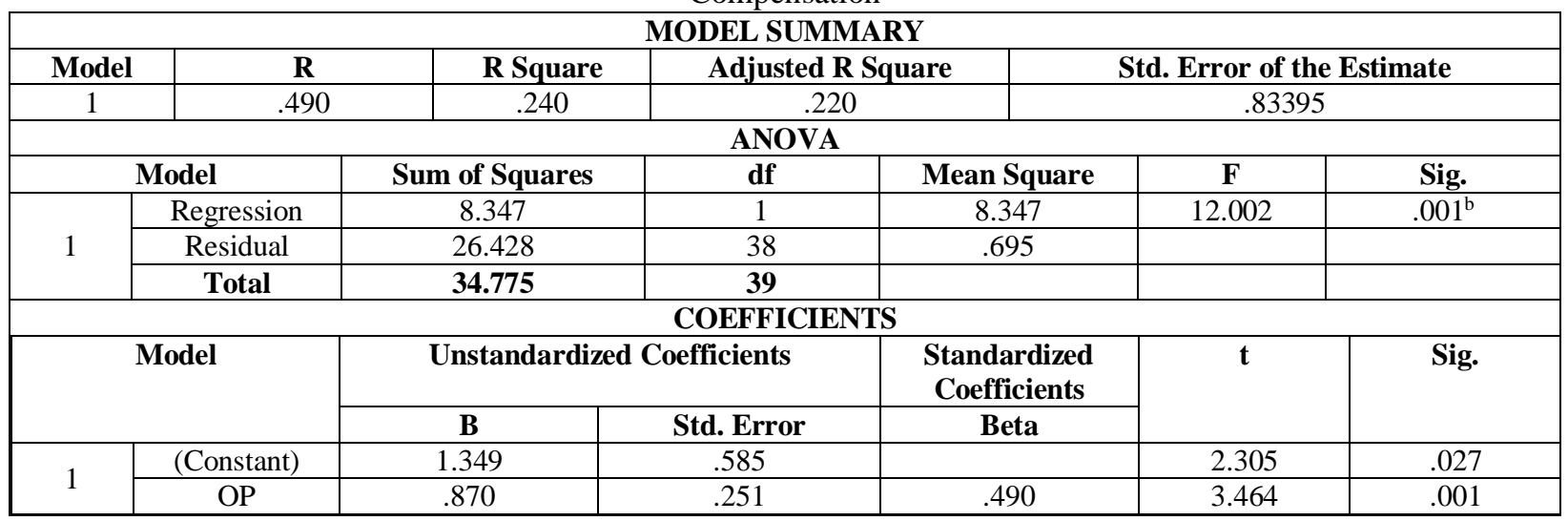

Predictors: (Constant), Organizational Performance

Dependent Variable: CEO'S Compensation 
The results in Table 4 indicate a model fit $(\mathrm{F}=12.002, \mathrm{P}<0.05)$. The findings further reveal a significant effect of organizational performance on CEO'S compensation $\left(\mathrm{R}^{2}=.24, \mathrm{~F}=12.002, \mathrm{P}<0.05\right)$. This means that $24 \%$ of the variation in CEO'S compensation was explained by variation in organizational performance. The table further reveals that beta coefficient was significant $(\beta=0.87, \mathrm{t}=2.305, \quad \mathrm{P}<0.05) . \quad$ This suggests that CEO'S compensation changes by $87 \%$ for every unit change in organizational performance. Hypothesis one was thus supported.

The overall regression model can be stated as $\mathbf{C C}=\mathbf{1 . 3 4 9 + 0 . 8 7 0 P + \varepsilon}$.

\section{Discussion of the findings}

This section provides discussion of the results under each research objective and conceptual hypothesis. The findings of the study are discussed in comparison with the results of previous studies that are related to the study variables to reveal any consistencies or inconsistencies. The results are also discussed in relation to theories that underpin them.

The objective of the study was to establish the influence of organizational performance on CEO's compensation for firms listed at the NSE. Hypothesis one was confirmed by the results of the simple linear regression analysis $\left(\mathrm{R}^{2}=0.24, \mathrm{~F}=12.002\right.$ and $\left.\mathrm{P}<0.05\right)$. Further, the results revealed that the rate of change between the two variables was significant $(\beta$ $=0.87, \mathrm{t}=2.305$ and $\mathrm{P}<0.05$ ). These results are in line with previous studies that show a strong relationship between organizational performance and CEO's compensation, where firm performance was measured by return on asset (ROA) and return on equity (ROE). Jensen and Murphy (1990) found a positive and significant relationship between CEO'S cash components of and organizational performance measured by shareholder wealth. In addition, Joskow and Rose (1994) suggested a robust relationship between organizational performance measured by both market-based and accounting measures and CEO'S total compensation.

However, the current study expanded the measures of organizational performance to include the balanced scorecard elements of financial indicators, customer satisfaction, internal processes and learning and development. The results of the regression analysis on the balance scorecard measure revealed their significant relationships with CEO's compensation $\left(\mathrm{R}^{2}\right.$ $=0.137,0.067,0.171$ and 0.399). This implied that learning and development explained $39.9 \%$ of variations in CEO's compensation, internal processes explained $17.1 \%$ of the variations, financial indicators explained $13.7 \%$ of the variation while customer satisfaction explained $6.7 \%$ of the variations in CEO's compensation.

These results affirm the preposition of Kaplan and Norton (1992) who argued that organizational performance should not be viewed narrowly by 
focusing on the financial results but rather organizational performance measurement should as a whole consider the factors of drive and contribute to firm's performance like learning and development, internal processes and customer satisfaction. The results of the study revealed that firms listed at the NSE consider both the financial and non-financial indicators of organizational performance when making decisions on the level of CEO'S compensation. These findings are also in line with Esptein and Roy (2005) argument indicating that a growing number of companies now use non-financial metrics to evaluate CEO's performance.

The results of this study however contradict Tarus (2014) and Aduda (2011), which on executive compensation found no significant relationship between executive compensation and financial performance of firms. This could be explained by the fact that the two studies, while done in the Kenyan context, focused on the overall executive compensation and not the individual CEO. Besides, the studies were conducted for specific industries, namely insurance and banking while the current study included all the firms listed out at the NSE. The results of the study indicate that organization boards consider organizational performance in determining the level of compensation to offer the CEO's. This is explained by the theoretical propositions of the Agency theory that propose that owners of a firm delegate authorities to make decisions on their behalf to an agent, the CEO. The theory highlights the existence of an agency problem where a CEO and the firm's shareholders often have differing interest such that the CEO may make moves that are in her best interest even if they hurt the firm (Jensen and Mackling, 1976). As such, in deciding the level of CEO's compensation. Boards consider the organization's performance so as to influence the CEO's behavior and interest towards enhancing organizational performance.

\section{Conclusion and implications}

The purpose of this study was to investigate the influence of firm size and CEO'S power on the relationship between organizational performance and CEO'S compensation for firms listed at the NSE. The objective of this study was to establish the influence of organizational performance on the determination of CEO'S compensation for firms listed at the NSE.

The study revealed that the listed firms provided their CEO'S with a basic pay, benefits and perquisites including medical cover, pension, club membership, vehicle with driver and fuel, education fund for the family and security by body guard. However, the benefits package varied from one firm to another. Long term incentives were also offered in form of stock ownership but at minimal levels. Bonuses were provided to CEO'S largely based on firm performance and constituted a large portion of the CEO'S annual total remuneration. In respect to the studies' objective that sought to investigate 
the influence of organizational performance on CEO'S compensation, the results indicated that there was a positive and significant relationship between the organizational performance and CEO'S compensation. Organizational performance was measured using 4 sub-variables in line with balance score card that is; financial indicators, internal processes, customer satisfaction and learning and growth. A correlation analysis indicated a moderately positive and statistically significant relationship between financial indicators of performance and internal processes with CEO'S compensation. There was a positive but weak relationship between customer satisfaction and CEO'S compensation though the relationship was insignificant. The relationship between CEO'S compensation and learning and growth was positive and statistically significant. Of the four variables, learning and growth explained variations in CEO'S compensation to a higher degree, followed by internal processes, financial indicators and the lowest being customer satisfaction. Multiple regression for the effect of organization performance on CEO'S compensation indicated that organizational performance explains $24 \%$ of variations in CEO'S compensation. Financial indicators, internal processes and learning and growth reveal significant relationships with CEO'S compensation but insignificant relationship with customer satisfaction.

\section{References:}

1. Abed, S. Suwaidan, M. \& Slimani, S. (2014). The determinants of Chief Executive Officer Compensation in Jordanian Industrial Corporations, International Journal of Economics and Finance; Vol. 6, pp 110-118

2. Aduda, J. (2011). The Relationship between Executive Compensation and Firm Performance in the Kenyan Banking Sector, Journal of Accounting and Taxation, Vol. 3(6), 130-139

3. Alchian, A. \& Demsetz, H. (1972). Production, information costs, and economic organization. American Economic Review, 62: 777-795

4. Baiman, S. and Verrecchia R. (1995). 'Earnings and price-based compensation contracts in the presence of discretionary trading and incomplete contracting', Journal of Accounting and Economics, Vol. 20:1, pp. 93-121

5. Baptista, M. (2010). CEO Compensation and Firm Performance in France. HEC, Paris Thesis

6. Barney, J. B. (2002). Gaining and sustaining competitive advantage $\left(2^{\text {nd }}\right.$ ed.) Upper Saddle River, NJ: Pearson Education, Inc.

7. Bebchuk, L.A., \& Fried, J.M. (2004). Pay without performance. The unfulfilled promise of Executive Compensation, Cambridge, M.A. Harvard University Press 
8. Berle, A.A. \& Means, G.C. (1932). The Modern Corporation and Private Property, New York Macmillan

9. Bernardin, J. (2007). Human Resource Management, an Experiential Approach, 3rd Ed, Tata McGraw-Hill Publishing Co., New Delhi.

10. Bertrand, M. \& Mullainathan, S. (2001). Are CEO's rewarded for luck? The ones without principals are. Quarterly Journal of Economics, Vol. 116, pp 901-932

11. Brick, I.E., Oded, P. \& Wald, J. (2005). CEO Compensation, Director Compensation and Firm Performance, Journal of Corporate Finance Vol. 12, pg. 112-118

12. Brown, J., and Fraser, M. (2006). Approaches and perspective in social and Environmental Accounting; An overview of the conceptual landscape, Business Strategy and Environment. Vol: 15: 103-117

13. Buigut, K., Soi, N. \& Koskei, I. (2014). Determinants of CEO Compensation Evidence from UK Public Limited Companies, International Journal of Business and Management, Vol. 10, No. 1; 2015

14. Chalmers, K., Koh, P.S., Stapledon, G. (2006). 'The determinants of CEO compensation. Rent extraction or labor demand?' The British Accounting Review 38, 259-275

15. Chung, Y. (2010. CEO Ability, Pay, and Firm Performance. JEL Classification: G34, J24,J33

16. Cooper, D. R. \& Schindler, P.S. (2008). Business Research Methods, $10^{\text {th }}$ Edition, McGRAW-Hill.

17. Core, J., Guay, W. \& Larcker, D. (2003). Executive Equity Compensation and Incetives: A Survey. FRBNY Economic Policy Review, 9, 27-50.

18. Cyert, R., Sok-Hyon, K. \& Praveen, K. (2002). Corporate Governance, Take-overs, and Top-Management Compensation: Theory and Evidence. Management Science. 48:4, pp.. 453-69.

19. Deckop, J. R. (1988). 'Determinants of Chief Executive Officer Compensation.' Industrial and Labor Relations Review, Vol. 41, pp. 215-226.

20. Eisenhardt, K., (1989). Agency Theory. An Assessment and Review, Academy of Management Review, Vol. 14: 57-74

21. Epstein,M and Roy,M. (2002). Measuring and improving the Performance of Corporate Board. The Society of Management Accountants of Canada, Hamilton

22. Farmer, M. (2008). Chief Executive Compensation and Company Performance: a weak relationship or measurement weaknesses? Kingston University, UK 
23. Finkelstein, S. \& Hambrick D.C., (1989). Chief Executive Compensation: a study of the intersection of markets and political processes, Strategic Management Journal Vol. 10.

24. Fleming, G., \& Stellios, G. (2002). CEO compensation, Managerial Agency and boards of directors in Australia. Accounting Research Journal, 15(2), 126-145.

25. Guest, M.P. (2009). Board Structure and Executive Pay: evidence from the UK. Cambridge Journal of Economics, vol31.

26. Gunasekargea, A., and Wilkinson, M. (2002). CEO Compensation and firm performance: A New Zealand investigation. International Journal of Business Studies, 10(2), 45.

27. Healy, P. (1985). The effect of bonus schemes on accounting decisions, Jounal of Accounting and Economics, Vol. 7, pp. 85-107

28. Hijazi, S. T. \& Bhatti, K. K., (2007). 'Determinants of Executive Compensation and its Impacts on Organizational Performance.' Compensation \& Benefits Review, Vol. 39., No. 2, 58-68

29. Holmstom, B. \& Kaplan S. (2003). The state of US Corporate governance: What's right and what's wrong? Journal of Applied Corporate Finance, Spring:8-20

30. Izan, H. Y., Sidhu, B. \& Taylor, S. (1998). Does CEO pay reflect performance? Corporate Governance: an International Review, 6, 3947

31. Jensen, M. C. \& Murphy, K .J. (1990). Performance Pay and top management incentives; Journal of Political Economy, Vol. 98

32. Jensen, M.C. and Meckling, W.M. (1976). The theory of the firm: Managerial behavior, agency costs and ownership structure. Journal if Financial Economics, 3, 305-360.

33. Kaplan, R.S. and Norton, D.P.(2000). The Strategy-focused organization: How balanced scorecard companies thrive in the new business environment, Harvard business school press, Cambridge.

34. Kaplan, R.S. and Norton, D.P.(1996). The Balanced Scorecard, Havard Business School Press, Cambrdge, M A.

35. Kerr, J. and Bettis, R. A. (1987). Boards of Directors, top management compensation and shareholder returns, Academy of Management Journal, Vol 30: 645-664

36. Khanna, V. (2016). Determinants of CEO Compensation, International Journal of Management Excellence, 6(2)

37. Kubo, K. (2001). The Determinants of Executive Compensation in Japan and the UK. Working paper series, No. 2001-2, Institute of Economic Research Hitotsubashi University. 
38. Lambert, R. A., Larcker, D. F., and Weigelt, K. (1991). 'How Sensitive is Executive Compensation to Organizational Size?' Strategic Management Journal, Vol. 12, pp. 395-402.

39. Leonard, J. (1990). Executive pay and Firm Performance, Industrial and labour relations review, Vo. 43, pp 13-29

40. Main, G. M., O'Reilly, C. A. and Wade, J. B. (1995). 'The CEO, the board of directors and executive compensation: economic and psychological perspectives', Industrial and Corporate Change, Vol. 4 pp293-332

41. Malkzadeh, A. (2002). Implications of CEO structural and ownership powers, board ownership and composition on the market's reaction to Antitakeover Charter Amendments. Journal of Applied Business Research, Vol. 14, No. 3: 53-62

42. Morck, R., Shleifer, A., Vishny R.W. (1990). Do Managerial objectives drive bad acquisitions? Journal of Finance, Vol. 45, pp 3148

43. Ongore, V. (2008). The Effect of Ownership Structure Board Effectiveness and Managerial Discretion on Performance of listed Companies in Kenya, unpublished $\mathrm{PhD}$ Thesis, UoN.

44. Ozkan, N. (2011). CEO Compensation and Firm Performance: an Empirical Investigation of UK Panel Data, European Financial Management, Vo. 17, pp 260-285

45. Owen D. (2006). Emerging issues in sustainability reporting, Journal Business Strategy and the environment, Vol. 15: pp217-218

46. Parthasarathy, A., Menon, K. \& Bhattacherjee, D. (2006), Executive Compensation, Firm Performance and Governance, Economic and Political Weekly

47. Penrose, E.T., (1995). The theory of the growth of the firm, New York: Wiley

48. Porter, M. (1980). Competitive Strategy, Free Press, New York

49. Post J. (2002). Redefining the corporation: Stakeholder management and original wealth, Stanford University press, Palo Alto

50. Ramaswamy, (2000). A study of the Determinants of CEO compensation in India. MIR Management International Review, 40(2), 167.

51. Reed, R., Lemak, D.J. \& Mero, N.P. (2000). Total quality management and sustainable competitive advantage. Journal of Quality Management, Vol. 5 No. 1, 5-26.

52. Reich R. (1998). The new meaning of corporate social responsibility, Asian Business and Management, Vol 4: pg. 95-115 
53. Rose, N. and Joskow, P. (1994). CEO pay and firm performance: Dynamics, asymmetries, and Alternative performance measures. Journal of Financial Economics, 3(4), 305-360

54. Sapp, S. G. (2007). The impact of Corporate Governance on Executive Compensation.

55. Shah, S. Z., Javed, T. \& Abbas M. (2009). Determinants of CEO compensation, Emperical Evidence from Pakistani Listed Companies, International Research Journal of Finance and Economics

56. Sigler, K.J. (2011). CEO Compensation and Company Performance. Business and Economics Journal, Volume 31.

57. Simon, H. A. (1957). Compensation of Executives. Sociometry 20: 3235.

58. Sonenshine, R., Larson, N. and Cauvel, M. (2016) Determinants of CEO Compensation before and after the Financial Crisis, Modern Economy, 7,1455-1477.

59. Tarus, K. E., Basweti, A. K. and Nyaoga, B. R. (2014). The Relationship between Executive Compensation and Financial Performance of Insurance companies in Kenya, Research Journal on Finance and Accounting, Vol. 5 (1), 113-122

60. Upadhaya, B., Munir, R., \& Blount, Y. (2014). Association between Performance Measurement Systems and Organizational Effectiveness. International Journal of Operations \& Production Management, 34(7), 2-2.

61. Wade, J. B., Porac, J. F. \& Pollock, T. G. (1997). Worth, Words and the Justification of Executive Pay, Journal of Organizational Behaviour, Vol. 18, John, W. and sons. 